\title{
EFFECT OF MAGNESIUM SULFATE ON DOPPLER INDICES AND FETAL CIRCULATION IN CASES OF SEVERE PRE-ECLAMPSIA
}

\author{
By \\ Ahmed A. Moussa, Abd El-Moneim M. Zakarya and Ahmed O. Abd El- \\ Motaal
}

Obstetrics and Gynecology Department, Faculty of Medicine, Al-Azhar University

E-mail: ahmedmoussa3387@gmail.com

\begin{abstract}
Background: In women with severe PE, the use of magnesium sulfate $\left(\mathrm{MgSO}_{4}\right)$ is indicated for prevention and control of acute convulsions. Several randomized trials have compared the efficacy of $\mathrm{MgSO}_{4}$ with other anticonvulsants in women with eclampsia, and the rates of recurrent seizures and maternal death significantly reduced with $\mathrm{MgSO}_{4}$ as compared with other anticonvulsants.
\end{abstract}

Objective: To assess the effect of magnesium sulfate injection on Doppler indices and fetal circulation in cases of severe pre-eclampsia.

Patients And Methods: This was a prospective study that conducted on one hundred pregnant women suffering from pre-eclampsia, selected from the Obstetrics and Gynecology Department of Al-Hussein University Hospital from January 2018 to December 2018, evaluated before and after administration of magnesium sulfate, Doppler ultrasound was carried out to measure umbilical artery blood flow.

Results: The results showed that a significant improvement in Doppler measurements and out come with treated groups $\left(\mathrm{MgSO}_{4}\right)$ group more than the control group.

Conclusion: $\mathrm{MgSO}_{4}$ proved to cause many hemodynamic changes as it has a vasodilator effect on maternal and fetal blood vessels. Doppler indices in the umbilical arteries significantly changed after administration of $\mathrm{MgSO}_{4}$ in patients with severe preeclampsia.

Key words: Magnesium sulfate, Doppler indices, Pre-eclamsia, fetal circulation.

\section{INTRODUCTION}

Preeclampsia is an endothelial disorder unique to human pregnancy, with multiple organ involvement; especially kidney lesion, defined as "glomerular endotheliosis", represents a specific variant of thrombotic microangiopathy characterized by glomerular endothelial swelling with loss of endothelial fenestrae and occlusion of the capillary lumens; the lesion, however, is not specific of preeclampsia, as it was found in women with normal pregnancy as well as in both non- proteinuric and proteinuric hypertension and is consequently not, as earlier believed, pathognomonic of pre-eclampsia (Shah \& Khalil, 2015; Vieira \& Khalil, 2016 and Bellomo, 2018).

The cardinal features of this syndrome are new-onset hypertension (beyond the 20th gestation week) and proteinuria $>300$ $\mathrm{mg} / 24 \mathrm{~h}$. Recent classifications may consider a diagnosis of preeclampsia in the absence of proteinuria, when signs of maternal organ or feto-placental 
dysfunction are present, (Magee et al., 2015).

The clinical course of severe preeclampsia is characterized by the progressive deterioration of both maternal and fetal conditions. Although delivery is still the only definitive treatment, expectant management for early onset severe pre-eclampsia has been shown to have beneficial effects on neonatal outcomes (Sakae et al., 2017).

A widespread consensus exists on the necessity of treating severe hypertension ( $\geq 160 \mathrm{mmHg}$ systolic or $100-110 \mathrm{mmHg}$ diastolic). Treatment is directed at achieving a BP around $140 \mathrm{mmHg}$ systolic and $85-90 \mathrm{mmHg}$ diastolic. Overcorrection of BP is discouraged as it may lead to maternal-fetal hypoperfusion. Caution is advised when using shortacting nifedipine, as it may cause profound hypotension and may potentiate side effects of $\mathrm{MgSO}_{4}$ given for the prophylaxis or treatment of preeclampsia (Dennis et al., 2015 and Too and Hill., 2013).

In women with severe PE, the use of magnesium sulfate $\left(\mathrm{MgSO}_{4}\right)$ is indicated for prevention and control of acute convulsions. Several randomized trials have compared the efficacy of $\mathrm{MgSO}_{4}$ with other anticonvulsants in women with eclampsia, and the rates of recurrent seizures and maternal death were significantly reduced with $\mathrm{MgSO}_{4}$ as compared with other anticonvulsants (Oliveira et al., 2017).

Although, there are a few studies assessing the effect of magnesium sulfate on fetal circulation, their results have showed a reduction in the resistance index, pulsatility index and systolic/diastolic ratio in the uterine and umbilical arteries (Rezavand et al., 2016). Intravenous administration of magnesium sulfate in pregnant women with severe preeclampsia resulted in a decrease in umbilical artery, uterine artery, and fetal middle cerebral artery Doppler indices with reduced resistance to blood flow in these vessels (Maged et al., 2016).

The aim of this study was to assess the effect of magnesium sulfate injection on Doppler indices and fetal circulation in cases of severe pre-eclampsia.

\section{PATIENTS AND METHODS}

This was a prospective study that was conducted on one hundred pregnant women suffering from pre-eclampsia, selected from the Obstetrics and Gynecology Department of Al-Hussein University Hospital during the period from Jan 2018 to Dec 2018.

\section{Inclusion criteria:}

Severe pre-eclampsia (B1P 160/110 $\mathrm{mmHg}$, Proteinuria), single pregnancy, gestational age 24-34 week, intact membranes and abnormal umbilical artery Doppler wave-form (Absent end diastolic flow).

\section{Exclusion criteria:}

Twin pregnancy, chronic hypertension, fetal death, fetal malformation, known intolerance to $\mathrm{MgSO} 4$, chronic diseases as anemia and diabetes mellitus, reversed end diastolic flow and all patients were subjected to the following:

- Complete medical history.

- Clinical Examinations.

- Laboratory Investigations: Complete blood picture, urine 
analysis "for proteinuria", random blood sugar and kidney function tests including blood urea and serum creatinine.

\section{- Radiological Investigations:}

Doppler ultrasound examination of the pregnant women for detection of: Uterine artery index and umbilical artery index

All patients with severe pre-eclampsia were admitted to the high-risk unit. Participants gave informed consents before management, and approval by ethical committee was obtained.

$\mathrm{MgSO}_{4}$ was given by IV route in a dose of $4 \mathrm{~g}$ IV loading dose administered over $15 \mathrm{~min}$ followed by $1 \mathrm{~g} /$ hour as a maintenance infusion dose. Duration of treatment did not exceed 24 hours. All patients were checked by ultrasound and Doppler examination for uterine artery and umbilical artery index after administration of $\mathrm{MgSo}_{4}$ in therapeutic doses.

Primary outcome: Eclampsia, Fetal or Neonatal death (any death upto 28 day including stillbirth), Severe maternal morbidity (respiratory depression, cardiac arrest, coagulopathy, ICU admission), and Drug side effects.

Secondary outcome: Pre-eclampsia, Maternal mortality, Neonatal morbidity (APGAR score $<7$ at $5 \mathrm{~min}$ ), Admission to neonatal ICU, Mode of delivery for antepartum or intrapartum severe preeclampsia, Post-partum hemorrhage, and Abruptio placenta.

\section{RESULTS}

The demographic data of the studied groups showed that the age of group $\mathrm{A}$ ranged between 22-32 years with a mean age of $27.44 \pm 3.52$ years while in group B the age ranged between 23-31 years with a mean age of $28.10 \pm 2.72$ years there was no statistical significant difference between both groups of the study regarding age. The BMI of group $\mathrm{A}$ ranged between 22-41 with a mean BMI of $28.34 \pm 3.3$ while in group B the BMI ranged between 23-35 with a mean value of $29.14 \pm 2.53$ there was no statistical significant difference between both groups of the study regarding BMI $(\mathrm{P}>0.05)$.

Laboratory findings: The AST in group A ranged from $27-49$ with mean value $37.06 \pm 4.90$ and in group B ranged from $29-46$ with mean value $38.08 \pm 4.53$. ALT in group A ranged from 27-49 with mean value $38.06 \pm 4.90$ and in group B ranged from 29-46 with mean value 38.08 \pm 4.53 . There was no statistical significant difference between the two studied groups regarding AST and ALT (P > 0.05). The Blood urea in group A ranged from 24128 with mean value $55.34 \pm 15.427$ and in group B ranged from 22-46 with mean value $30 \pm 6.224$. S. creatinine in group A ranged from $0.75-2.1$ with mean value $1.2876 \pm 0.297$ and in group B ranged from $0.325-1.1$ with mean value $0.8025 \pm 0.213$. There was statistical significant difference between the two studied groups regarding blood urea and $\mathrm{S}$. creatinine $(\mathrm{P}<0.05)$. The maternal $\mathrm{Hb}$ level in group A ranged from 9.9-16.0 with mean value $12.21 \pm 1.45$ and in group B ranged from 9.7-15.0 with mean value 11.916 \pm 1.32 . There was no statistical significant difference between the two studied groups regarding $\mathrm{Hb}$ conc. $(\mathrm{P}>0.05)$ (Table $\mathbf{1})$. 
AHMED A. MOUSSA et al.,

Table (1): Comparison between the two studied groups regarding laboratory findings

\begin{tabular}{|c|c|c|c|}
\hline $\begin{array}{l}\text { Laboratory } \\
\text { findings }\end{array}$ & $\begin{array}{c}\text { Groups } \\
\text { Group A } \\
\text { Experimen } \\
\text { tal group" }\end{array}$ & $\begin{array}{c}\text { Group B } \\
\text { “Control } \\
\text { group" }\end{array}$ & P Value \\
\hline AST & $37.06 \pm 4.90$ & $38.08 \pm 4.53$ & $>0.05$ \\
\hline ALT & $38.06 \pm 4.90$ & $38.08 \pm 4.53$ & $>0.05$ \\
\hline Blood urea & $55.34 \pm 15.43$ & $58.88 \pm 13.72$ & $>0.05$ \\
\hline S. creatinine & $1.2876 \pm 0.30$ & $1.3264 \pm 0.28$ & $>0.05$ \\
\hline Hb conc & $12.214 \pm 1.45$ & $11.916 \pm 1.32$ & $>0.05$ \\
\hline
\end{tabular}

The systolic blood pressure in experimental group was significantly lower than the control group $(\mathrm{p}<0.05)$, while the diastolic blood pressure was less than the control but the difference was insignificant (Table 2).

Table (2): Comparison between the two studied groups regarding blood pressure after treatment

\begin{tabular}{|c|c|c|c|}
\hline Groups & $\begin{array}{c}\text { Group A } \\
\text { "Experimental } \\
\text { group" }\end{array}$ & $\begin{array}{c}\text { Group B } \\
\text { "Control } \\
\text { group" }\end{array}$ & $\begin{array}{c}\text { t-test } \\
\text { P Value }\end{array}$ \\
\hline $\begin{array}{c}\text { Systolic blood } \\
\text { pressure }\end{array}$ & $161.5 \pm 9.25$ & $170.2 \pm 10.3$ & $<0.001^{*}$ \\
\hline $\begin{array}{c}\text { Diastolic blood } \\
\text { pressure }\end{array}$ & $120.6 \pm 7.65$ & $128.5 \pm 8.65$ & $<0.001^{*}$ \\
\hline
\end{tabular}

The umbilical artery Doppler finding on admission showed an increasing in PI, RI and S/D ratio than the normal value, while the PSV showed decrease than the normal value. In comparing the two studied group on admission, it was found that there was no significant difference between the two groups regarding all umbilical Doppler studied parameters.
There was a significant decrease in both PI and RI in experimental group less than the control group, while there was a significant increase in PSV in experimental group more than the control group, while $\mathrm{S} / \mathrm{D}$ ratio show a decrease in experimental group but this decrease was insignificant (Table 3). 
Table (3): Comparison between the two studied groups regarding umbilical artery Doppler before and after treatment

\begin{tabular}{|c|c|c|c|}
\hline $\begin{array}{l}\text { U/A Doppler Groups } \\
\text { Before treatment }\end{array}$ & $\begin{array}{c}\text { Group A } \\
\text { "Experimental } \\
\text { group" }\end{array}$ & $\begin{array}{c}\text { Group B } \\
\text { “Control } \\
\text { group” }\end{array}$ & $\begin{array}{c}\text { t-test } \\
\text { P Value }\end{array}$ \\
\hline PI & $1.14 \pm 0.095$ & $1.16 \pm 0.089$ & $>0.05$ \\
\hline RI & $0.64 \pm 0.046$ & $0.66 \pm 0.051$ & $<0.05^{*}$ \\
\hline S/D ratio & $2.95 \pm 0.246$ & $2.96 \pm 0.269$ & $>0.05$ \\
\hline PSV & $38.48 \pm 2.960$ & $38.22 \pm 2.940$ & $>0.05$ \\
\hline U/A Doppler After treatment & $0.95 \pm 0.086$ & $1.15 \pm 0.105$ & $<0.001^{*}$ \\
\hline PI & $0.59 \pm 0.054$ & $0.65 \pm 0.046$ & $<0.001^{*}$ \\
\hline RI & $2.61 \pm 0.186$ & $2.95 \pm 0.227$ & $<0.001^{*}$ \\
\hline PSV ratio & $42.9 \pm 3.900$ & $38.6 \pm 3.217$ & $<0.001^{*}$ \\
\hline
\end{tabular}

The comparison between the two studied groups regarding maternal complications, regarding incidence of eclampsia in group A was $6.0 \%$, while in control group was $24.0 \%$, there was a significant increase in the incidence of eclampsia in control group more than the exponential group, also the HELLP in group $\mathrm{B}$ was significantly higher than group A $(\mathrm{p}<0.05)$. The incidence of different neonatal complication was higher in group B "control group" more than group A "Experimental group, but this increase was insignificant. The neonatal complications included preterm, IUGR, NICU, still birth and Apgar score less than 7 at $5 \mathrm{~min}$. (Table 4).

Table (4): Comparison between the two studied groups regarding maternal complications and neonatal complications.

\begin{tabular}{|c|c|c|c|c|c|}
\hline \multirow{2}{*}{ Groups } & \multicolumn{2}{|c|}{$\begin{array}{c}\text { Group A } \\
\text { "Experimental } \\
\text { group" }\end{array}$} & \multicolumn{2}{|c|}{$\begin{array}{l}\text { Group B } \\
\text { "Control } \\
\text { group" }\end{array}$} & \multirow[t]{2}{*}{ P Value } \\
\hline & No. & $\%$ & No. & $\%$ & \\
\hline $\begin{array}{l}\text { Eclampsia } \\
\text { Yes } \\
\text { No }\end{array}$ & $\begin{array}{c}3 \\
47\end{array}$ & $\begin{array}{c}6.0 \\
94.0\end{array}$ & $\begin{array}{l}12 \\
38\end{array}$ & $\begin{array}{l}24.0 \\
76.0\end{array}$ & 0.012 \\
\hline $\begin{array}{l}\text { HELLP } \\
\text { Yes } \\
\text { No }\end{array}$ & $\begin{array}{c}9 \\
41\end{array}$ & $\begin{array}{l}18.0 \\
82.0\end{array}$ & $\begin{array}{l}19 \\
31\end{array}$ & $\begin{array}{l}38.0 \\
62.0\end{array}$ & 0.0256 \\
\hline \multicolumn{6}{|l|}{ Neonatal complications } \\
\hline Preterm & 4 & 8.0 & 8 & 16.0 & $>0.05$ \\
\hline IUGR & 6 & 12.0 & 7 & 14.0 & $>0.05$ \\
\hline NICU & 4 & 8.0 & 9 & 18.0 & $>0.05$ \\
\hline Still birth & 1 & 2.0 & 3 & 6.0 & $>0.05$ \\
\hline APGAR $<7$ at 5 min. & 5 & 10.0 & 8 & 16.0 & $>0.05$ \\
\hline
\end{tabular}

In group " $\mathrm{A} " 24.0 \%$ had normal vaginal delivery, while in group " $\mathrm{B}$ " $10.0 \%$ only delivered normal, there was an increasing in normal delivery in experimental group but this increasing was insignificant (Table 5). 
Table (5): Comparison between the two studied groups regarding mode of delivery

\begin{tabular}{|c|c|c|c|c|c|}
\hline \multirow{2}{*}{ Groups } & \multicolumn{2}{|c|}{$\begin{array}{c}\text { Group A } \\
\text { "Experimental } \\
\text { group" }\end{array}$} & \multicolumn{2}{|c|}{$\begin{array}{c}\text { Group B } \\
\text { "Control } \\
\text { group" }\end{array}$} & \multirow{2}{*}{ P Value } \\
\cline { 2 - 5 } Mode of delivery & No. & $\%$ & No. & $\%$ & \\
\hline NVD & 12 & 24.0 & 5 & 10.0 & \multirow{2}{*}{$>0.05$} \\
\hline C.S. & 38 & 76.0 & 45 & 90.0 & \multirow{2}{*}{} \\
\hline
\end{tabular}

\section{DISCUSSION}

Our study revealed that there was no significant difference between both groups regarding age and BMI, this results obey the inclusion criteria, with normal distribution of both age and BMI to eliminate the effect of the demographic data on the net results.

Abdelrahman and his Colleagues (2019) found in their study that there was no significant difference between both groups of their study regarding age and BMI that run in line with our results. Liver functions tests "AST and ALT" showed insignificant difference in both studied groups. In agreement with our results, Peralta et al. (2014) found no difference in levels of AST, ALT, and total bilirubin between women with preeclampsia and normal control subjects.

Our study revealed a non-significant difference between both groups regarding serum urea and serum creatinine as well as hemoglobin concentration. Ekun and his Coworkers (2018) found in their study that there was a significant increase in the serum blood urea and serum creatinine in cases of preeclampsia which may be due to decreased urinary clearance secondary to reduced glomerular filtration rate and increased reabsorption and this findings were conflicting with our results.

Patil and his Colleagues (2016) found a significant elevation of blood urea and serum creatinine in cases of severe preeclampsia than those with mild preeclampsia or controls which disagreed with our study.

In our study, on comparing between the two studied groups regarding blood pressure after treatment, it was found that the systolic blood pressure in experimental group was significantly lower than the control group, while the diastolic blood pressure was less than the control but the difference was insignificant.

In agreement with our study, Takenaka et al, (2016) found that systolic and diastolic BPs after administration of magnesium sulfate were significantly lower than those before administration. In most effective cases, BP decreased to the mild level range for at least $2 \mathrm{~h}$ after administration. Belfort et al. (2013) reported that $45.7 \%$ of patients with severe preeclampsia decreased their BPs by loading 4-6 g of magnesium sulfate.

Our study revealed a significant decrease in umbilical artery Doppler parameters including pulsatility index, RI, S/D ratio and PSV in patients with magnesium sulfat administration. Maged and his Colleagues (2016) concluded in their study that the use of magnesium sulfat in cases of severe preeclampsia resulted in a decrease in umbilical artery Doppler index with reduced resistance to blood flow in these vessels which run in 
lines with our results. Rezavan and his Colleagues (2016) found that there was a significant decreasing effect on umbilical artery pulsatility index of women with severe PE.

Dasgupta and his Coworkers (2012) found in a randomized placebo controlled trial after full dosage of prophylactic magnesium sulfate in preeclampsia, reported that post-magnesium sulfate UA (PI) dropped fundamentally in contrast with pre-magnesium sulfate which runs in line with our study. Rantonen and his Colleagues (2001) found that the use of $\mathrm{MgSO}_{4}$ resulted in decrease of the uterine artery. Therefore, the hypothesis that the vasodilator effect of the magnesium was more evident where the higher vascular resistance was found confirmed.

In our results, it was found that maternal complications in group A was significantly lower than the complication in group B, which include of eclampsia and HELLP. On the other hand, the neonatal complication which include of preterm, IUGR, NICU, still birth and APGAR $<7$ at 5 min showed insignificant difference between the two studied groups. Finally the mode of delivery showed a non-significant increase in normal delivery in group A "experimental group" more than the control group.

Oliveira and his Colleagues (2017) concluded in their study that, after the administration of $\mathrm{MgSO}_{4}$, an increase in the impedance to flow in the ophthalmic artery and consequently a reduction in cerebral perfusion after the use of $\mathrm{MgSO}_{4}$. This can explain how $\mathrm{MgSO}_{4}$ protects women with severe PE against cerebral damage and prevents acute convulsions in these patients which results in decrease in complications in preeclamptic patients which inagreement with our results. Adekanmi and his Colleagues (2019) concluded that the uterine artery PI is the best predictor of $\mathrm{PE}$, whereas the combinations of uterine and umbilical arteries PSV best predict severity of PE among high-risk pregnant women as well as it has no effect on fetal outcome.

Abdelrahman et al., (2019) found that there was no significant difference between both groups of their study regarding the effect on fetal outcome which disagree with our results. Sedek (2015) found that there was a significant decrease in the uterine artery parameters by Doppler (UAPI, RI, S/D) after injection of magnesium sulfate in preeclampsia patients which was in agreement with our results. Souza and his Colleagues (2010) reported that there was a significant reduction of the RI, PI and S/D of both uterine arteries.

\section{CONCLUSION}

We can conclude that $\mathrm{MgSO}_{4}$ proved to cause many hemodynamic changes as it has vasodilator effect on maternal and fetal blood vessels. Doppler indices in the umbilical arteries are significantly changed after administration of $\mathrm{MgSO}_{4}$ in patients with severe preeclampsia so it should be given to all patients with severe preeclampsia.

\section{REFERENCES}

1. Abdelrahman TN, Youssry MA, Radwan AM and Ahmed A (2019): Impact of intravenous infusion of labetalol combined with magnesium sulfate versus hydralazine combined with magnesium sulfate on fetomaternal hemodynamics in severe 
preeclampsia. Ain-Shams J Anesthesiol., 11: 5-13.

2. Adekanmi AJ, Roberts A, Akinmoladun JA, and Adeyinka AO (2019): Uterine and umbilical artery doppler in women with pre-eclampsia and their pregnancy outcomes. Niger Postgrad Med., J 26: 106-12.

3. Belfort MA, Anthony J, Saade GR, Allen JC and Group NS (2013): A comparison of magnesium sulfate and nimodipine for the prevention of eclampsia. N Engl J Med.; 348: 304 311.

4. Bellomo G (2018): Hypertensive disorders of pregnancy. In: "Disorders of Blood Pressure Regulation; Phenotypes, Mechanisms, and Therapeutic Options; Berbari AE and Mancia G eds", pbl. Springer Intl Publishing, Switzerland, Part IX, Chapt 44, pp 763-796.

5. Dasgupta S, Ghosh D, Seal SL, Kamilya G, Karmakar M and Saha D (2012): Randomized controlled study comparing effect of magnesium sulfate with placebo on fetal umbilical artery and middle cerebral artery blood flow in mild preeclampsia at $\geq 34$ weeks gestational age. J Obstet Gynaecol Res., 38: 763-771.

6. Dennis AT, Chambers $\mathbf{E}$ and Serang K (2015): Blood pressure assessment and frst-line pharmacological agents in women with eclampsia. Int $\mathbf{J}$ Obstet Anesth., 24: 247-251.

7. Ekun OA, Olawumi OM, Makwe $\mathrm{CC}$ and Ogidi NO (2018): Biochemical Assessment of Renal and Liver Function among Preeclamptics in Lagos Metropolis. Intl J Reprod Med 2018(ID 1594182): 6 pages.

8. Maged AM, Hashem AMT, Gad Allah SH, El-Mahy M, Mostafa WAI and Kotb A (2016): The effect of loading dose of magnesium sulfate on uterine, umbilical, and fetal middle cerebral arteries Doppler in women with severe preeclampsia: A case control study. J Hyperten Preg., 35(1): 91-99.

9. Magee LE, Pels A, Helewa MD, Rey E, von Dadelszen P; Canadian Hypertensive Disorders of Pregnancy (HDP) Working Group and Canadian Hypertensive Disorders of Pregnancy HDP Working Group (2015): The hypertensive disorders of pregnancy (29.3). Best Pract Res Clin Obstet Gynecol., 29(5): 643-657

10. Oliveira CA, de Sa RAM, Zamprogno KV, da Matta FG and Araújo F (2017): Magnesium sulfate and ophthalmic artery Doppler velocimetry in patients with severe preeclampsia: a case series. Journal of Medical Case Reports, 11: 326-331.

11. Patil S, Jyothi A, Babu A and Goud VGK (2016): A study on Liver function tests and Renal function tests in Preeclampsia. Intl J Biomed Res., 7(10): 713-717.

12. Peralta Pedro ML, Basavilvazo R, Cruz Avalar A, Sanchez Ambroz S, Guzman A and Martinez G (2014): Clinical significance of the laboratory determinations of preeclamptic patients. Gynecologia y Obstetriciade, 72:57-62. 
13. Rantonen $T$, Kääpä $P$, Grönlund $J$, Ekblad U, Helenius H, Kero $P$ and Välimäki I (2001): Maternal magnesium sulfate treatment is associated with reduced brain-blood flow perfusion in preterm infants. Crit Care Med., 29(7): 1460-5.

14. Rezavan N, Farshchian N, Gaviri A, Veisi $F$ and Jallilian $N$ (2016): Evaluation of the effect of magnesium sulfate on the parameters of Doppler flow velocity or the uterine arteries and fetal outcomes in severe preeclampsia. Acta Med Mediter 32: 1959-1963.

15. Sakae C, Sato Y, Kanbayashi S, Taga A, Emoto I, Maruyama S, Mise $H$ and Kim $T$ (2017): Introduction of management protocol for early-onset severe pre-eclampsia. $\mathbf{J}$ Obstet Gynecol Res., 43(4): 644-652.

16. Sedek AA (2015): Effect of the loading dose of magnesium sulfate on the Doppler velocimetry parameters in the uterine, umbilical and fetal middle cerebral arteries in severe preeclampsia. Al-Azhar Assuit Med J., 13(4): 56-62.

17. Shah D and Khalil RA (2015): Bioactive factors in uteroplacental and systemic circulation link placental ischemia to generalized vascular dysfunction in hypertensive pregnancy and preeclampsia. Biochem Pharmacol., 95: 211-226.
18. Souza AS, Amorim MM and Coutinho IC (2010): Effect of the loading dose of magnesium sulfate (MgSO4) on the parameters of Doppler flow velocity in the uterine, umbilical and middle cerebral arteries in severe preeclampsia. Hypertens Pregnancy, 29(2): 123-34.

19. Takenaka S, Matsuoka R, Maruyama D, Kawashima A, Koide $\mathrm{K}$, and Sekizawa A (2016): Magnesium sulfate has an antihypertensive effect on severe pregnancy induced hypertension. Hypertens Res Pregnancy, 4: 11-15.

20. Too $G$ and Hill JB (2013): Hypertensive crisis during pregnancy and postpartum period. Semin Perinatol., 37: 280-287.

21. Vieira JSP and Khalil RA, (2016): Mechanisms of Endothelial Dysfunction in Hypertensive Pregnancy and Preeclampsia. Adv Pharmacol., 77: 361-431. 
تأثنير حقن عقار كبريتات الماغنيسيوم على مؤشر ات الفحص

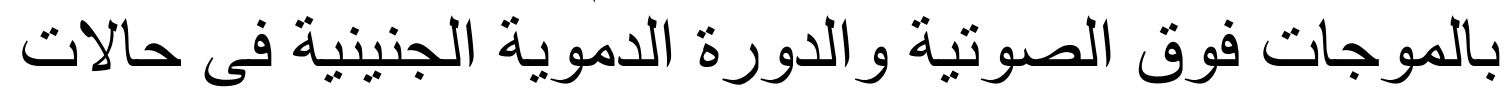
تسمح الحمل الثديدة

أحمد عطية محمد موسى، عبد المنعم محمد زكريا، أحمد أسامه عبد المتعال

قسم النساء والتوليد، كلية الطب، جامعة الأزهر

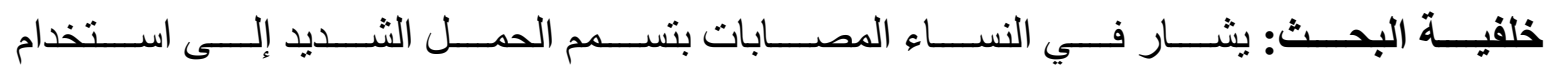

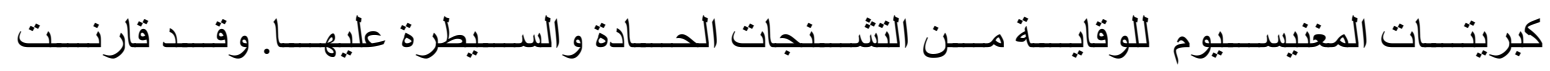

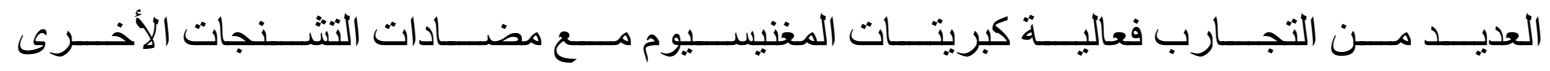

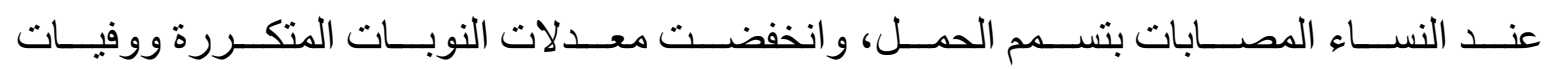
الأمهات بشكل كبير مع كبريتات المغنيسيوم مقارنة بمضادات التشنجات الأخرى.

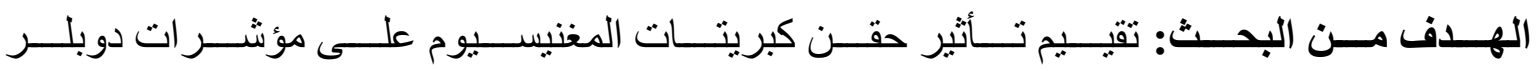
ودورة الجنين في حالات تسمم الحمل الثديد.

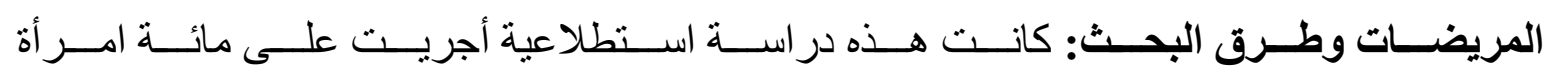

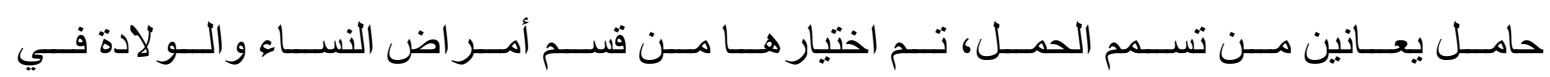

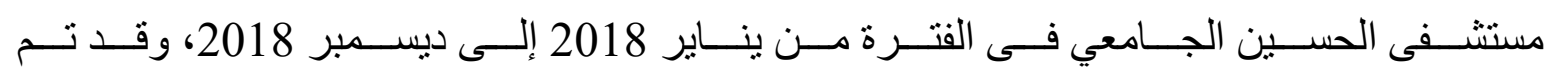

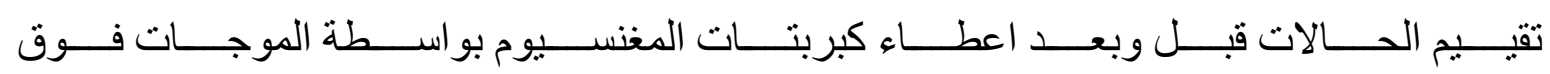
الصوتية لقياس معدل سريان الدم بالثريان السري.

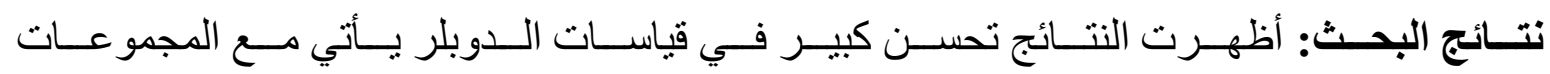
المعالجة بكبريتات المغنبسيوم أكثر من المجمو عة الضابطة.

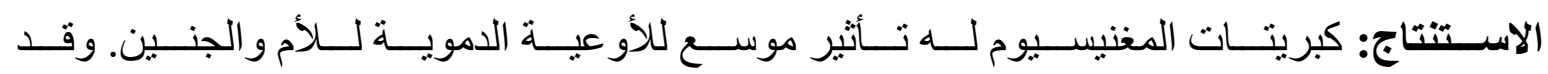

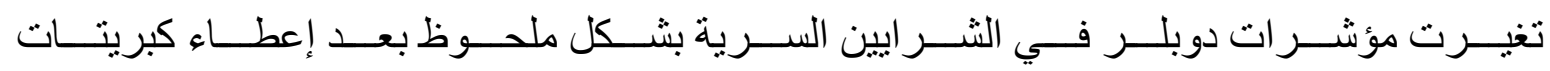
المغنيسيوم في المرضى الذين يعانون من تسمم الحمل الثديد. 